\title{
Article
}

\section{Implementasi Pengawasan Dinas Lingkungan Hidup Dalam Mengatasi Pencemaran Lingkungan Pada Kawasan Industri di PT. Perkebunan Nusantara VI}

\author{
Ridwan ${ }^{1 *}$ Sukma Delima²
}

This article is an open access article distributed under the terms and conditions of the Creative Commons Attribution-ShareAlike 4.0 International (CC BY SA ) License (https://creativecommo ns.org/licenses/bysa/4.0/).

\section{Jurnal Politik dan} Pemerintahan Daerah ISSN 2686-2271

Fakultas Ilmu Sosial dan Ilmu Politik, Universitas Muara Bungo Jl. Diponegoro No. 27, Muara Bungo-Jambi, (0747) 323310

\author{
${ }^{1}$ Program Studi Ilmu Pemerintahan Fakultas Ilmu Sosial Dan Ilmu Politik, Universitas \\ Muara Bungo, Kabupaten Bungo, Provinsi Jambi \\ 2 Program Studi Ilmu Pemerintahan Fakultas Ilmu Sosial Dan Ilmu Politik, Universitas \\ Muara Bungo, Kabupaten Bungo, Provinsi Jambi \\ * Correspondence Author: iwan09ukm@gmail.com
}

Abstract: This study aims to determine how the implementation of the Environmental Service's supervision of palm oil industrial waste and its management. This study uses a qualitative method. The data collection techniques are interviews, observation, and documentation. The subjects of this study were the Head of the Environmental Service, Staff of the Environmental Service, Public Relations of PTPN VI (Persero), RT Desaa Tirta Kencana, RT Desa Sapta Mulya, and the community around the PTPN VI (Persero) Factory. The supervision carried out by the Environmental Service in overcoming environmental pollution in the palm oil industrial area, Rimbo Ilir District, Tebo Regency has not been effective. This is because PT. Perkebunan Nusantara VI (Persero) Rimbo Bujang still disposes of liquid waste through ditches and tributaries that empties into the Alay River, causing pollution. Several obstacles to the supervision of the Environmental Service on the management of waste water from the palm oil industry, Rimbo Ilir District, Tebo Regency, including the weather factor and the limited human resources (Human Resources) factor.

Keywords: Environmental Pollution, Monitoring, Pollution.

Abstrak: Penelitian ini bertujuan untuk mengetahui bagaimana pelaksanaan pengawasan Dinas Lingkungan Hidup terhadap limbah industri kelapa sawit dan pengelolaannya. Penelitian ini menggunakan metode kualitatif. Teknik pengumpulan datanya adalah, wawancara, observasi, dan dokumentasi. Subjek penelitian ini adalah Kadis Dinas Lingkungan Hidup, Staf Pegawai Dinas Lingkungan Hidup, Humas PTPN VI (Persero), RT Desaa Tirta Kencana, RT Desa Sapta Mulya, dan Masyarakat sekitar Pabrik PTPN VI (Persero). Pengawasan yang dilakukan oleh Dinas Lingkungan Hidup dalam mengatasi pencemaran lingkungan pada kawasan industri minyak kelapa sawit Kecamatan Rimbo Ilir Kabupaten Tebo belum efektif. Hal ini dikarenakan PT. Perkebunan Nusantara VI (Persero) Rimbo Bujang masih membuang limbah cair melalui parit dan anak sungai yang bermuara ke Sungai Alay sehingga menyebabkan pencemaran. Beberapa hambatan pengawasan Dinas Lingkungan Hidup terhadap pengelolaan air limbah industri minyak kelapa sawit Kecamatan Rimbo Ilir Kabupaten Tebo, diantaranya adalah Faktor cuaca dan Faktor terbatasnya SDM (Sumber Daya Manusia).

Kata Kunci: Pencemaran Lingkungan, Pengawasan, Pencemaran. 


\section{Pendahuluan}

Pembangunan merupakan upaya yang dilakukan untuk menuju ke arah yang lebih baik dalam rangka menjamin kelangsungan hidup masyarakat banyak. Pembangunan dilaksanakan untuk meningkatkan kualitas kehidupan masyarakat. Peningkatan pelaksanaan pembangunan dapat dilihat dari pembangunan yang terus dilakukan secara berkelanjutan. Pembangunan berkelanjutan merupakan proses pembangunan dengan prinsip memenuhi kebutuhan sekarang tanpa mengorbankan pemenuhan kebutuhan generasi masa depan. Salah satu masalah yang harus dihadapi untuk mencapai pembangunan berkelanjutan adalah bagaimana memperbaiki keseimbangan lingkungan yang terganggu atau mengalami kerusakan. Tujuan dasar dari Pembangunan Berkelanjutan adalah untuk mengakomodir segala perubahan yang terjadi setelah berakhirnya era pembangunan millennium dengan memasukkan beberapa tujuan baru(Setianingtias et al., 2019).

Dalam pandangan umum, bahwa pembangunan industri di Indonesia bertujuan untuk meningkatkan kemakmuran dan kesejahteraan rakyat secara adil dan merata dengan memanfaatkan dana, Pembangunan akan dinilai berkualitas bila memperhatikan lingkungan sekitar(Rosana, 2018) .Sumber daya alam, dan/atau hasil budidaya serta dengan memperhatikan keseimbangan dan kelestarian lingkungan hidup serta meningkatkan pertumbuhan ekonomi secara bertahap, mengubah struktur perekonomian kearah yang lebih baik, maju, sehat dan lebih seimbang sebagai upaya untuk mewujudkan dasar yang lebih kuat dan lebih luas bagi pertumbuhan ekonomi pada umumnya, serta memberikan nilai tambah bagi pertumbuhan industri khususnya, meningkatkan keikutsertaan masyarakat dan kemampuan golongan ekonomi lemah, termasuk pengrajin agar berperan secara aktif dalam pembangunan industri.

Indonesia sebagai negara agraris memiliki sumber daya alam melimpah, terdiri dari bumi, air, dan kekayaan alam yang terkandung di dalamnya. Potensi tersebut merupakan karunia dan amanat Tuhan Yang Maha Esa, yang harus dipergunakan untuk mewujudkan kesejahteraan umum dan kemakmuran rakyat, sebagai amanat Pancasila dan Undang-Undang Dasar Negara Republik Indonesia Tahun 1945. Dalan pasal 28 Ayat (1) UUD 1945 disebutkan bahwa negara berkewajiban melindungi hak warga negara untuk medapatkan lingkungan hidup yang baik dan sehat. Pengelolaan kekayaan alam yang bijak mesti harus mengkaji permasalahan lingkungan agar dapat menjamin tercapainya hak warga negara untuk dapat menikmati lingkungan yang sehat bahkan sampai kepada generasi selanjutnya.

Pengelolaan lingkungan hidup perlu diikuti dengan tindakan berupa pelestarian sumber daya alam dalam rangka memajukan kesejahteraan umum seperti tercantum dalam Undang-Undang Dasar 1945. Salah satunya upaya pemerintah untuk menjamin terjaganya lingkungan hidup adalah dengan melahirkan Undang-Undang Nomor 32 Tahun 2009 tentang perlindungan dan Pengelolaan Lingkungan Hidup (UUPPLH).

Perkembangan industri ini memberikan dampak positif antara lain berupa kenaikan devisi Negara, transfer teknologi dan penyerapan tenaga kerja. Namun demikian, selain memberikan dampak yang positif ternyata perkembangan perkembangan disektor industri juga memberikan dampak yang negatif, yaitu berupa limbah industri yang bila tidak dikelola dengan baik dan benar akan mengganggu keseimbangan lingkungan, sehingga yang pembangunan berwawasan tidak dapat tercapai. Karena itu, perlu adanya program penataan terhadap ketentuan peraturan perundang-undangan maupun persyaratan perizinan yang berkaitan dengan masalah lingkungan. 
Pada dasarnya penataan ruang seperti perencana tata ruang, pemanfaatan ruang, dan pengenalian pemanfaatan ruang terhadap ketentuan dalam peraturan perundang-undangan lingkungan hidup harus dilakukan dengan sukarela pada para penanggung jawab pabrik, namun kenyataan masih banyak yang belum taat, untuk itu perlu ada dorongan melalui program-program penataan, bahkan adakalanya harus dilakukan upaya paksa dalam bentuk program penegakan hukum.

Pencemaran yang disebabkan oleh bahan kimia dapat dibagi menjadi tiga jenis pencemaran, yaitu pencemaran ke tanah, pencemaran udara, dan pencemaran air. Perubahan keadaan bahan kimia yang terbesar dalam tiga medium fisik lingkungan ini, baik secara langsung maupun tidak langsung akan berpengaruh terhadap kesejahteraan hidup manusia dan mahkhluk hidup lainnya. Pengaruh dari pencemaran ini dapat terjadi dalam penggunaan air untuk keperluan minum, masak dan lain-lain.

Berdasarkan dengan pembangunan yang berwawasan lingkungan maka pemerintah dalam hal ini diwakili oleh Dinas Lingkungan Hidup Kota Tebo mengantisipasi sedini mungkin agar tidak terjadi pencemaran sehingga pemerintah harus menekankan pada penggunaan teknologi yang bersih lingkungan karena perhatian terhadap lingkungan tidak hanya kepada masyarakat semata tetapi untuk perusahaan itu sendiri. Terkait dengan peran pemerintah sebagai regulator dalam pencemaran lingkungan, pemerintah dalam hal ini diwakili oleh Dinas Lingkungan Hidup Kota Tebo telah membuat program untuk mendukung penanganan tersebut diantaranya:

Terselenggaranya pengawasan dalam sebuah institusi yakni untuk menilai kinerja suatu institusi dan memperbaiki kinerja sebuah institusi. Oleh karena itu disetiap perusahaan harus rutin adanya sistem pengawasan. Dengan demikian pengawasan merupakan instrumen pengendalian yang melekat pada setiap tahap oprasional perusahaan. Fungsi pengawasan dalam dilakukan setiap saat, baik selama proses manajemen atau administrasi berlangsung maupun setelah berakhir untuk mengetahui tingkat pencapaian tujuan suatu organisasi atau kerja. Fungsi pengawasan dilakukan terhadap perencanaan dan kegiatan pelaksanaannya.

Kesadaran terhadap lingkungan tidak hanya menciptakan segala sesuatu yang indah dan berisi saja, tetapi ada kewajiban dari setiap manusia untuk menghormati dan menghargai hak orang lain serta kehidupan sekitarnya. Sehingga kita jumpai tindakan orang atau bahkan sekelompok orang yang menjalankan suatu kegiatan industri hanya mengejar kepentingan dan kemajuannya sendiri tanpa menghiraukan hak orang lain dan lingkungan dimana industri itu berdiri. Kelalaian dari industri tersebut juga dapat menyebabkan kerusakan dan pencemaran pada lingkungan, yang nantinya akan merugikan orang disekitar industri tersebut.

Pencemaran lingkungan hidup menurut Undang-Undang Nomor 32 Tahun 2009 Pasal 1 Tentang Perlindungan Dan Pengelolaan Lingkungan Hidup adalah : "Pencemaran lingkungan hidup adalah masuk atau dimasukkannya makhluk hidup, zat, energi, dan/atau komponen lain ke dalam lingkungan hidup oleh kegiatan manusia sehingga melampaui baku mutu lingkungan hidup yang telah ditetapkan".

Pengendalian pencemaran yang dijelaskan pada Pasal 13 Ayat (1) : "Pengendalian pencemaran dan/atau kerusakan lingkungan hidup dilaksanakan dalam rangka pelestarian fungsi lingkungan hidup". Ayat (2) : "Pengendalian pencemaran dan/atau tidak kerusakan lingkungan hidup sebagaimana dimaksud pada ayat (1) meliputi : a. pencegahan; b. penanggulangan; dan c. pemulihan."

Berdasarkan observasi peneliti, bahwa pencemaran udara disebabkan oleh setiap perusahaan merupakan salah satu dampak yang ditimbulkan dari kegiatan 
produk yang dilakukan oleh perusahaan tersebut dikarenakan kegiatan produksi tersebut akan menghasilkan asap buang

Kabupaten Tebo merupakan salah satu pusat produksi minyak sawit mentah (Crude Palm Oil CPO), terdapat industri pengelolaan CPO di Kabupaten Tebo. Khususnya pengelolaan CPO yang berada di kawasan Desa Karang Dadi Kecamatan Rimbo Ilir yang di kelola oleh PT Perkebunan Nusantara VI (Persero).

PT Perkebunan Nusantara VI (Persero) adalah salah satu perusahaan yang bergerak di bidang perkebunan kelapa sawit dan pabrik pengolahan kelapa sawit yang berdomisili di Desa Karang Dadi Kecamatan Rimbo Ilir Kabupaten Tebo , dalam pengelolahan kelapa sawit tentu adanya dampak dari pabrik tersebut. Dampak dari pabrik tersebut yaitu limbah. Limbah dari pabrik sawit tersebut terdiri dari limbah padat dan limbah cair. Dimana pembuangan akhir dari limbah cair industri perusahaan tersebut ada yang dibuang ke Sungai Alay jalan Sapta Desa Tirta Kencana. Sedangkan sungai tersebut masih digunakan oleh masyarakat untuk keperluan sehari-hari.

Pembuangan kubikan limbah berwarna hitam pekat dan bau tersebut dibuang melalui sebuah parit melewati parit jalan Camar desa Sapta Mulia dan limbah tersebut mengalir ke sungai Alay. Dibuangnya limbah PKS PTPN VI rimdu ini, mengakibatkan Sungai Alay tercemar dan mengancam ekosistem didalamnya. Sekitar 102 penduduk masyarakat yang menggunakan air Sungai Alay untuk keperluan sehari-sehari pun menjadi terganggu.

Pihak PTPN VI Rimdu terkadang tidak terlalu serius menanggapi persoalan, karena tidak ada ikan yang mati di Sungai Alay, PTPN VI mengklaim kalau limbah tersebut tidak berbahaya, itu tidak benar. Timbah itu tetap berbahaya terhadap kelangsungan ekosistem Sungai Alay. Dengan persoalan ini masyarakat mendesak agar pihak dinas terkait dalam hal ini Dinas Lingkungan Hidup Kabupaten Tebo jangan tutup mata. Segera turun kelapangan dan jangan hanya selesai dengan pertemuan-pertemuan formal.

Efektivitas fungsi pengawasan yang dilakukan oleh pemerintah maupun masyarakat sangat berperan penting dalam mengawal peraturan perundangundangan tersebut demi terjaganya kelestarian lingkungan. Instalasi pemerintah daerah yang berwenang dalam mengawasi suatu usaha/kegiatan yang berhubungan dengan lingkungan hidup di tingkat daerah adalah Dinas Lingkungan Hidup Kabupaten Tebo.

Laporan warga juga mengatakan bahwa setiap musim penghujan seperti ini, limbah sengaja dibuang ke Sungai Alay karena kolam limbah PKS tidak mampu lagi menampung limbah. Masyarakat menegaskan bahwa pihak PTPN VI Unit Rimbu harus segera menghentikan aksi buang limbah ke Sungai Alay karena dari berubahnya warna air Sungai Alay ke warna hitam, ini sudah pencemaran lingkungan.

Dari wawancara beberapa warga yang dekat tempat tinggalnya di pabrik kelapa sawit PTPN VI Rimdu, pabrik tersebut menimbulkan pencemaran lingkungan salah satunya sumur yang berpengaruh. Semenjak dari tahun 2005 sampai dengan sekarang masyarakat salau mengeluhkan dampak dari pabrik tersebut. Masyarakat tidak pernah demo, tetapi sering awak media yang datang untuk menanyakan hal tersebut.

Masyarakat yang terkena pencemaran lingkungan dari pabrik kelapa sawit PTPN VI Rimdu ada 30 KK di Jl. Rimdu Unit 6 Desa Tirta Kencana dan 30 KK di Jl. Camar Unit 7 Desa Sapta Mulya. Pihak manajemen PTPN VI Rimdu selalu mengadakan sosialisasi dengan masyarakat sekitar. Solusi yang di lakukan pihak PTPN VI dalam membantu masyarakat, dalam bentuk memeperbaiki jalan, bangunan sekolah, seperti memberikan fasilitas sekolah. 


\begin{tabular}{c|l|c}
\multicolumn{3}{|c}{ Tabel 1. Data Masyarakat yang Terkena Pencemaran Lingkungan } \\
No & \multicolumn{1}{|c|}{ Desa } & Jumlah KK \\
1 & Desa Karang Dadi & $37 \mathrm{KK}$ \\
2 & Desa Tirta Kencana & $43 \mathrm{KK}$ \\
3 & Desa Sapta Mulya & $43 \mathrm{KK}$
\end{tabular}

Berdasakan uraian di atas, maka penulis ingin mengetahui sejauh mana pengawasan Dadan Lingkungan Hidup terhadap pengelolahan limbah industri minyak sawit di Kabupaten Tebo dan mengetahui pengelolaan limbah dari salah satu industri minyak sawit PT Perkebunan Nusantara VI (Persero) sehingga dalam penelitian ini penulis memilih judul "Implementasi Pengawasan Dinas Lingkungan Hidup Dalam Mengatasi Pencemaran Lingkungan Pada Kawasan Industri Di PT. Perkebunan Nusantara VI".

\section{Pembahasan}

\section{Implementasi Pengawasan Dinas Lingkungan Hidup dalam Mengatasi Pencemaran lingkungan pada Kawasan Industri di Kecamatan Rimbo Ilir Kabupaten Tebo}

Dinas Lingkungan Hidup merupakan unsur pendukung pelaksana tugas pemerintah daerah dalam perumusan pelaksanaan kebijakan daerah di bidang pengelolaan lingkungan hidup yang dipimpin oleh seorang Kepala Badan yang berada di bawah dan bertanggung jawab kepada Bupati melalui Sekretaris Daerah. Dinas Lingkungan Hidup mempunyai tugas pokok melaksanakan penyelenggaraan Pemerintahan Daerah di bidang Pengelolaan Lingkungan Hidup, berdasarkan kebijakan yang ditetapkan oleh Bupati. Ditingkat daerah yaitu di Kabupaten Tebo, lembaga yang mengurus dan mengawasi masalah lingkungan hidup adalah Dinas Lingkungan Hidup dan Perhubungan dan Perhubungan Kabupaten Tebo.

Mengenai kewenangan pemerintah daerah Kabupaten Tebo dalam hal ini adalah Dinas Lingkungan Hidup diatur dalam Peraturan Bupati Tebo Nomor 94 Tahun 2019 tentang Kedudukan, Susunan Organisasi, Tugas Dan Fungsi Serta Tata Kerja Dinas Lingkungan Hidup dan Perhubungan, dalam Pasal 12 ayat (3) menyebutkan bahwa: "Dinas Lingkungan Hidup dan Perhubungan mempunyai fungsi mempunyai tugas penyusunan perumusan dan pelaksanaan kebijakan, penyusunan norma, standar, prosedur dan kriteria, dan pemberian bimbingan teknis dan supervisi, serta pemantauan, evaluasi, dan pelaporan dibidang pelayanan kebersihan dan pengelolaan sampah, limbah cair dan limbah B3 serta pengelolaan ruang terbuka hijau dan pemakaman." Serta dalam hal pengawasan diatur dalam Pasal 12 huruf e menyebutkan bahwa : "pelaksanaan pemantauan, analisa, evaluasi, dan pelaporan dibidang pelayanan kebersihan dan pengelolaan sampah, limbah cair dan limbah B3 serta pengelolaan ruang terbuka hijau dan pemakaman"

Dinas Lingkungan Hidup dalam hal pengawasan dijalankan oleh Bidang Pengendalian Pencemaran dan Kerusakan Lingkungan Hidup yang diatur dalam Pasal 18 Peraturan Bupati ini. Selanjutnya Bidang Pengendalian Pencemaran dan Kerusakan Lingkungan Hidup ini membawahi Sub Bidang Pengawasan Dampak Lingkungan yang mempunyai tugas diatur dalam Pasal 20 huruf g, yaitu : "Pelaksanaan pengawasan terhadap penerima izin lingkungan dan izin perlindungan dan pengelolaan lingkungan."

Pemerintah Kabupaten Tebo melalui Dinas Lingkungan Hidup dan Perhubungan secara berangsur-angsur memperlihatkan kinerjanya. Setiap ada laporan mengenai pencemaran limbah cair pabrik kelapa sawit selalu tanggap dan turun langsung kelapangan. Dengan adanya laporan terkait limbah cair yang dibuang langsung ke sungai tanpa pengolahan oleh PT. Perkebunan Nusantara VI (Persero). Pihak Dinas Lingkungan Hidup membenarkan jika PT. Perkebunan 
Nusantara VI (Persero) masih belum optimal dalam pengolahan limbah cairnya. Dengan adanya pencemaran tersebut sangat diperlukan pengawasan dari Badan Ligkungan Hidup. Dinas Lingkungan Hidup Kabupaten Tebo melakukan pengawasan terhadap mengatasi pencemaran lingkungan pada kawasan industri di Kecamatan Rimbo Ilir Kabupaten Tebo. Berdasarkan hasil wawancara dengan beberapa informan diketahui bahwa pengawasan yang dilakukan oleh Dinas Lingkungan Hidup, antara lain:

1. Pengawasan Langsung

Berdasarkan hasil wawancara diketahui bahwa pengawasan langsung yang dilakukan oleh Dinas Lingkungan Hidup yaitu melakukan pengawasan terhadap perusahaan industri yang ada di Kecamatan Rimbo Ilir khusunya terhadap perusahaan pabrik kelapa sawit, karena limbah yang dihasilkan oleh pabrik kelapa sawit jauh lebih banyak jika dibandingkan oleh industri lain. Pengawasan rutin yang dilakukan langsung oleh Dinas Lingkungan Hidup Kabupaten Bungo ke PT. Perkebunan Nusantara VI (Persero). Pengawasan rutin ini dilakukan sekali enam bulan, pengawasan ini dilakukan dengan cara mengambil sampel air limbah ke kolam IPAL dan diuji ke laboratorium. Dinas Lingkungan Hidup melakukan pengawasan rutin ini guna untuk melihat apakah hasil laporan yang diberikan sama dengan kenyataan yang ada di lapangan.

Pasal 1 angka 29 Peraturan Menteri Lingkungan Hidup Nomor 5 Tahun 2014 tentang Baku Mutu Air Limbah menyebutkan bahwa : "Air limbah adalah sisa dari suatu usaha dan/atau kegiatan yang berwujud cair." Sedangkan limbah cair industri adalah buangan hasil proses atau sisa dari suatu kegiatan industri yang berwujud cair.

Limbah cair yang dihasilkan pabrik kelapa sawit harus diolah terlebih dahulu sehingga parameternya berada dibawah baku mutu air limbah yang sudah ditetapkan baru bisa dibuang ke sumber air atau sungai. Tujuan pengelolaan limbah cair PT. Perkebunan Nusantara VI (Persero) adalah sebagai berikut:

1. Mempertahankan kualitas air limbah pabrik kelapa sawit agar tetap di bawah baku mutu yang telah ditetapkan sebelum di buang ke badan air sungai

2. Meminimalkan dampak negatif dan memaksimalkan dampak positif terhadap lingkungan hidup.

Dari kegiatan pabrik akan dihasilkan limbah padat, cair, serta gas. Limbah cair pabrik kelapa sawit diolah di suatu kolam instalasi yang disebut Instalasi Pengolahan Air Limbah (IPAL) karena limbah cair yang dihasilkan oleh pabrik kelapa sawit memiliki BOD (biochemical oxygen demand) $25.000 \mathrm{ppm}$, perlu diolah sehingga BOD yang dibuang ke badan air harus sesuai dengan peraturan perundangundangan yang berlaku.

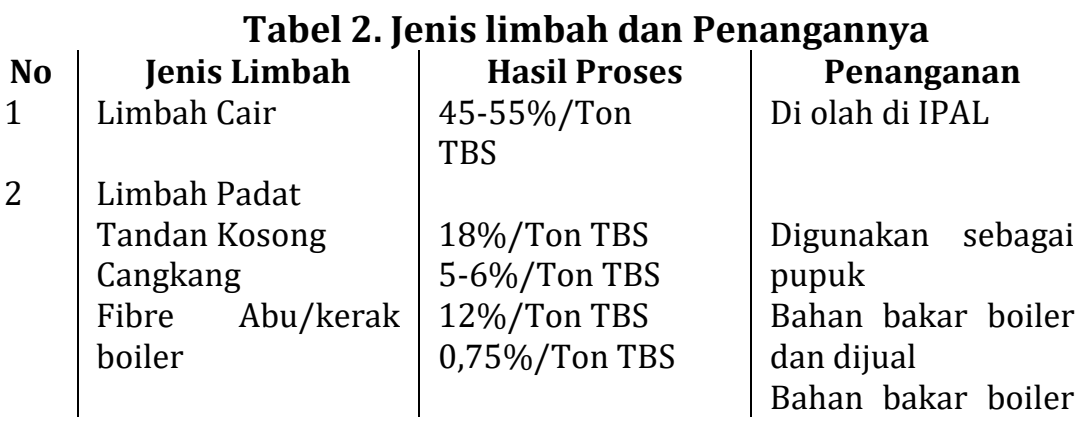


\begin{tabular}{l|l|l} 
& & \\
& & dan dijual \\
Dijual \\
Dust collector
\end{tabular}

Sumber : PT. Perkebunan Nusantara VI (Persero), 2020

Pengelolaan limbah cair yang dihasilkan oleh pabrik kelapa sawit ini diatur dalam Pasal 16 Peraturan Menteri Lingkungan Hidup Nomor 5 Tahun 2014 Tentang Baku Mutu Air Limbah, sebagai berikut: "Setiap usaha dan/atau kegiatan sebagaimana dimaksud dalam pasal 3 ayat (1) wajib:

a. melakukan pemantauan kualitas air limbah paling sedikit 1 (satu) kali setiap bulannya sesuai dengan parameter yang telah ditetapkan dalam izin pembuangan air limbah;

b. melaporkan hasil pemantauan sebagaimana dimaksud pada huruf a sekurang-kurangnya 3 (tiga) bulan sekali kepada penerbit izin pembuangan air limbah, dengan tembusan kepada Menteri dan gubernur sesuai dengan kewenangannya.

Hasil wawancaran dengan Bapak Edizal Amri selaku Humas PTPN VI (Persero) diketahui bahwa pihak PTPN VI (Persero) belum sepenuhnya melakukan pelaporan secara berkala atas hasil pemantauan kepada Dinas Lingkungan Hidup dan Perhubungan Kabupaten Tebo dikarenakan keterbatasan sumber daya manusia.

c. laporan hasil pemantauan sebagaimana dimaksud pada huruf b paling sedikit memuat:

1) catatan debit air limbah harian;

2) bahan baku dan/atau produksi senyatanya harian;

3) kadar parameter baku mutu limbah cair; dan

4) penghitungan beban air limbah.

d. laporan sebagaimana dimaksud pada huruf c disusun berdasarkan format pelaporan sebagaimana Lampiran XLVIII Peraturan Menteri."

Setelah melihat bagaimana pengelolaan limbah cair pabrik kelapa sawit yang diatur dalam peraturan perundangan-undangan, maka selanjutnya akan penulis bandingkan dengan pengelolaan limbah cair pabrik kelapa sawit yang dilakukan oleh PT. Perkebunan Nusantara VI (Persero) sendiri. Pengelolaan limbah cair pada PT. Perkebunan Nusantara VI (Persero) tidak dilakukan sekaligus namun ada beberapa tahapan yang harus dilakukan. Adapun tahapan tersebut yakni:

\section{a. Fat Pit}

Limbah dari pabrik kelapa sawit dialirkan masuk ke dalam Fat Pit. Pada fat pit ini terjadi pemanasan dengan menggunakan uap dari BPV (back pressure vessel) atau yang disebut dengan alat yang berperan dalam distribusi uap di pabrik kelapa sawit. Pemanasan ini diperlukan untuk memudahkan pemisahan minyak dengan lumpur, karena pada fat pit ini masih dimungkinkan untuk melakukan pengutipan minyak. Limbah dari fat pit ini kemudian dialirkan ke kolam cooling pond yang berguna untuk mendinginkan limbah yang telah di panaskan. 


\section{b. Cooling Pond}

Limbah yang masuk ke cooling pond akan mengendapkan lumpur dan mendinginkan limbah. Setelah dari cooling pond I limbah kemudian masuk ke cooling pond II untuk dilakukan proses pendinginan yang sama dengan cooling pond I. Limbah dari cooling pond II kemudian dialirkan ke kolam anaerobic I, II, III.

c. Acidification

Berfungsi sebagai proses pra-kondisi bagi limbah sebelum masuk ke kolam anaerobic. Pada kolam ini limbah akan di rombak menjadi VFA (volatile fatty acid) atau asam yang mudah menguap.

\section{d. Anaerobic}

Proses penguraian senyawa, senyawa kompleks menjadi senyawa yang lebih sederhana di anaerobic pond I dan II. Proses ini ditandai dengan adanya gelembung, gelembung gas methane dan CO2 sebagai hasil dari proses fermentasi secara anaerob. BOD air limbah yang diharapkan setelah proses ini adalah 5000 ppm.

Keadaan kolam 3 atau yang disebut dengan kolam anaerobic I ini hampir sama dengan kolam 2 yaitu lumpur hampir meluap hingga keluar kolam. Dan juga penulis melihat banyak bekas lumpur yang sudah mengendap di tepian kolam, yang berarti lumpur dari permukaan kolam sering meluap hingga keluar. Keadaan ini harusnya diperhatikan oleh pekerja PT. Perkebunan Nusantara VI (Persero), agar pengolahan limbah cair dapat berjalan dengan baik.

\section{e. Fakultatif}

Merupakan kolam stabilisasi setelah kolam anaerob. Dikolam ini terjadi proses penguraian secara anaerobic di dasar kolam. Pada proses ini terjadi dimana bahan anaerob diubah menjadi CO2, H2O serta sel bakteri dan alga baru. Oksigen yang dihasilkan dari fotosintesis alga dimanfaatkan oleh bakteri anaerob untuk mendegradasi limbah anaerob selanjutnya. Dan penguraian secara aerobic diatas permukaan kolam. Di kolam ini, organisme bakteri akan mengurai material organik. Karakteristik limbah pada kolam fakultatif yaitu Ph 7,6-7,8. BOD 600-800 ppm, COD 1250-1750 ppm. Aktivitas ini dapat diketahui dengan indikasi pada permukaan kolam yang tidak dijumpai sampah dan cairan tampak kehijau-hijauan.

Pada kolam ke 7 atau kolam fakultatif II ini adalah kolam yang paling besar ukurannya diantara kolam-kolam yang lain. Keadaan kolam yang penulis lihat secara langsung hanya tinggal air saja, tetapi parameter limbah cair yang ada pada kolam ini masih diatas baku mutu.

\section{f. Aerobic}

Kolam aerob dibuat relatif dangkal dengan tujuan agar cahaya matahari memungkinkan untuk menembus hingga ke dasar kolam. Supaya kolam terhindar dari kondisi anaerobic. Dikolam ini, terjadi penguraian secara sempurna senyawa organik yang berasal dari buangan dalam periode waktu yang relatif singkat.

Proses di kolam 8 dan 9 ini memerlukan oksigen melalui udara, oksigen diperlukan untuk pertumbuhan maupun respirasi dengan menggunakan aerator dan suplai oksigen yang cukup. Seharusnya 
pada kolam aeorob ini sudah memenuhi baku mutu sehingga boleh dibuang langsung ke badan air, tetapi kenyataanya pada kolam aeorob milik PT. Perkebunan Nusantara VI (Persero) ini masih diatas baku mutu dan masih harus diolah di kolam selanjutnya yaitu kolam sedimentasi.

\section{g. Sedimentasi}

Kolam ini bertujuan untuk mengendapkan partikel padat yang mengalir secara langsung dari kolam aeorob sehingga limbah yang keluar tidak menimbulkan kekeruhan pada saat dibuang ke badan air.

\section{h. Indikator}

Kolam ini berfungsi sebagai tempat untuk proses stabilisasi akhir dan untuk pencegahan-pencegahan darurat bila terjadi kegagalan operasi pengendalian limbah cair. Di kolam ini lah seharusnya parameter limbah yang akan dibuang ke badan air berada dibawah baku mutu sehingga aman untuk dibuang.

Pengelolaan limbah cair yang dilakukan oleh PT. Perkebunan Nusantara VI (Persero) dilakukan dengan bantuan kolam IPAL (Instalasi Pengolahan Air Limbah). Kolam IPAL ini jumlahnya ada 11, pada kolam terakhir yang disebut dengan Kolam Indikator inilah seharusnya parameter limbah sudah berada dibawah baku mutu air limbah yang telah ditetapkan di Peraturan Menteri Lingkungan Hidup Nomor 5 Tahun 2014 tentang Baku Mutu Air Limbah, jika parameter limbah dalam kolam ini sudah berada dibawah baku mutu, maka baru bisa dibuang ke badan sungai sehingga tidak terjadi yang namanya pencemaran.

Tetapi fakta yang ditemukan di lapangan berbeda, adanya laporan bahwa banyak pabrik kelapa sawit di Kabupaten Tebo diduga melakukan pembuangan limbah cair ke badan sungai tanpa melalui pengolahan limbah, termasuk salah satunya adalah PT. Perkebunan Nusantara VI (Persero). Hal ini sebagaimana dikeluhkan oleh warga atas limbar cari yang berasal dari pengolahan buah sawit PKS yang dibuang ke sungai Alay, Jalan Sapat Desa Tirtra Kecana. Tindakan yang dilakukan oleh PTPN VI dengan membuang limbah ke Sungai Alay telah diketahui secara umum dikarenakan kolam limbah yang terdapat pada pabrik tersebut tidak mampu lagi menampung limbah, namun kondisi tersebut memiliki dampak terhadap terhadap lingkungan, khususnya ekosistem air dan bagi masyarakat sebagai pengguna.

Ada upaya yang dilakukan oleh pihak RT setempat yang memberikan himbauan secara langsung kepada PTPN VI untuk menghentikan kegiatan pembuangan limbah tersebut, hal ini didasari kondisi air Sungai Alay yang sudah berubah warna, menandakan adanya pencemaran lingkungan. Hanya saja pihak PTPN VI mengabaikan permasalahan tersebut, padahal limbah tersebut tetap berbahaya terhadap kelangsungan ekosistem Sungai Alay. Adanya perbedaan pandangan antara masyarakat dengan pihak pemerintah, dimana perusahaan menganggap cairan yang berwarna hitam tersebut adalah air limpahan drainase air hujan di pabrik yang didalamnya terdapat endapan debu dan tanah disaluran parit tersebut, bukanlah limbah karena limbah itu dipergunakan untuk pupuk jadi tidak mungkin dibuang. Limbah Pabrik Kelapa Sawit PTPN VI Rimbu dua dipergunakan untuk pupuk Sawit. Karena Limbah tersebut bermanfaat 
untuk pupuk Sawit. Namun dibutuh uji labor untuk membenarkan pernyataan tersebut.

PT. Perkebunan Nusantara VI (Persero) membuang limbah ke Sungai Alay dengan keadaan parameter limbah tersebut berada diatas baku mutu, seharusnya PT. Perkebunan Nusantara VI (Persero) mempunyai standar khusus dalam pengolahan limbah, karena setiap pabrik kelapa sawit pasti menghasilkan limbah dan pencemaran lingkungan yang berbeda-beda, oleh karena itu perlu adanya standar khusus yang dibuat oleh PT. Perkebunan Nusantara VI (Persero) agar limbah yang dihasilkan tidak dibuang diatas baku mutu yang menyebabkan pencemaran. Seharusnya pengawasan Dinas Lingkungan Hidup untuk pabrik kelapa sawit yang menghasilkan limbah dilakukan setiap bulannya agar meminimalisir adanya pencemaran yang ditimbulkan yang menyebabkan terganggunya kegiatan masyarakat setempat.

Selain memperhatikan pengolahan limbah cair agar berada dibawah baku mutu, pembuangan limbah cair ke sungai yang parameternya sudah berada dibawah baku mutu juga harus diperhatikan waktunya. Tidak adanya waktu yang tetap untuk membuang limbah tersebut ke sungai. Seharusnya pembuangan limbah tersebut ditentukan kapan saja waktunya, agar pengolahan limbah cair lebih terarah dan PT. Perkebunan Nusantara VI (Persero) memiliki standar khusus dalam pengolahan limbahnya.

Pengelolaan limbah cair yang diatur dalam Peraturan Menteri Lingkungan Hidup Nomor 5 Tahun 2014 tentang Baku Mutu Air Limbah yang diatur dalam Pasal 16 dengan pengelolaan limbah cair yang dilakukan oleh PT. Perkebunan Nusantara VI (Persero) terdapat perbedaan. Dapat dilihat dari Pasal 16 huruf a, menyebutkan bahwa : "setiap usaha dan/atau kegiatan industri wajib melakukan pemantauan kualitas air limbah paling sedikit 1 (satu) kali setiap bulannya sesuai dengan parameter yang telah ditetapkan dalam izin pembuangan air limbah." Tetapi kenyataannya PT. Perkebunan Nusantara VI (Persero) melakukan pemantauan atau tes kualitas air limbah sekali dalam tiga bulan. Padahal yang sekali tiga bulan itu adalah waktu untuk melaporkan hasil pemantauan ke Dinas Lingkungan Hidup seperti diatur dalam Pasal 16 huruf b, menyebutkan bahwa :

"melaporkan hasil pemantauan sebagaimana dimaksud pada huruf a sekurangkurangnya 3 (tiga) bulan sekali kepada penerbit izin pembuangan air limbah, dengan tembusan kepada Menteri dan gubernur sesuai dengan kewenangannya."

Seharusnya PT. Perkebunan Nusantara VI (Persero) melakukan pemantauan tes kualitas air limbah sekali sebulan agar air limbah tersebut dapat di evaluasi secara maksimal dan melaporkan hasil pemantauan kualitas air limbah ke Dinas Lingkungan Hidup setiap tiga bulan.

Selain itu penulis juga melihat pengawasan yang dilakukan oleh Dinas Lingkungan Hidup berbeda dengan yang dikatakan oleh pihak PT. Perkebunan Nusantara VI (Persero). Tetapi kenyataannya pengawasan yang dilakukan langsung oleh Dinas Lingkungan Hidup hanya sekali satu tahun. Dan jika ada laporan dari masyarakat baru dilakukan pengawasan berkali-kali. Seharusnya Dinas Lingkungan 
Hidup melakukan pengawasan secara rutin sekali enam bulan seperti yang dikatakan. Atau lebih baik dilakukan sekali sebulan agar lebih maksimal.

Selanjutnya menurut hemat penulis, baku mutu air limbah yang dibuang oleh PT. Perkebunan Nusantara VI (Persero) sampai saat ini masih berada diatas baku mutu. Hal tersebut karena baik dari pihak PT. Perkebunan Nusantara VI (Persero) maupun dari pihak Dinas Lingkungan Hidup sama-sama tidak mau memberikan hasil tes uji laboratorium kualitas air limbah dari tahun 2018 keatas, mereka menyebutkan karena ada alasan tertentu.

2. Pengawasan Tidak Langsung

a. Laporan Triwulan Pemantauan Limbah Cair

Untuk bidang pengawasan, pabrik kelapa sawit termasuk PT. Perkebunan Nusantara VI (Persero) itu diwajibkan untuk menyampaikan laporan ke Dinas Lingkungan Hidup dan Perhubungan sekali tiga bulan. Contohnya hasil pengujian bulan Januari, Februari, dan Maret disampaikan pada bulan April, apakah laporan tersebut memenuhi baku mutu atau tidak. Hasilnya nanti akan di evaluasi.

\section{b. Sanksi Administratif}

Ketika Dinas Lingkungan Hidup melakukan pengawasan langsung yaitu pemeriksaan rutin sekali enam bulan ke pabrik kelapa sawit dan menemukan hasil di lapangan yang tidak sesuai dengan peraturan perundang-undangan yang berlaku, maka Dinas Lingkungan Hidup akan mengeluarkan sanksi administratif.

\section{c. Pencabutan Izin Lingkungan}

Didalam sanksi ini pabrik kelapa sawit dicabut izin lingkungannya. Sudah tidak boleh beroperasi lagi. Selanjutnya jika pabrik kelapa sawit melanggar aturan yang telah dibuat oleh Dinas Lingkungan Hidup, maka Dinas Lingkungan Hidup akan memberikan sanksi administratif berupa teguran tertulis, sanksi administratif paksaan pemerintah, pembekuan izin lingkungan, dan yang terakhir adalah pencabutan izin lingkungan. Dalam kasus PT. Perkebunan Nusantara VI (Persero) ini, sepanjang tahun 2017 Dinas Lingkungan Hidup hanya melakukan pengawasan langsung sekali setahun, dan pihak Dinas Lingkungan Hidup ketika melakukan pengawasan itu menemukan bahwa hasil tes laboratorium air limbah yang dibuang oleh PT. Perkebunan Nusantara VI (Persero) berada diatas baku mutu. Tetapi pihak Dinas Lingkungan Hidup sama sekali tidak memberikan sanksi apapun.

Menurut hemat penulis, seharusnya Dinas Lingkungan Hidup memberikan dahulu sanksi teguran tertulis agar PT. Perkebunan Nusantara VI (Persero) bisa memperbaiki sistem pengelolaan air limbahnya, tetapi karena tidak adanya sanksi apa-apa yang diberikan sepanjang tahun 2017, dari bulan Januari sampai Desember hasil tes laboratorium air limbah yang dibuang oleh PT. Perkebunan Nusantara VI (Persero) tetap berada diatas baku mutu. Seharusnya Dinas Lingkungan Hidup lebih meningkatkan sanksi tersebut sampai pada sanksi pembekuan izin lingkungan bahkan bisa sampai pada pencabutan izin lingkungan. Tetapi kenyataannya Dinas Lingkungan Hidup tidak tegas dalam melakukan pengawasan dan pemberian sanksi tersebut. 


\section{Hambatan pengawasan Dinas Lingkungan Hidup terhadap pengelolaan air limbah industri minyak kelapa sawit Kecamatan Rimbo Ilir Kabupaten Tebo.}

Berdasarkan hasil wawancara dengan informan diketahui bahwa Hambatan pengawasan Dinas Lingkungan Hidup terhadap pengelolaan air limbah industri minyak kelapa sawit Kecamatan Rimbo Ilir Kabupaten Tebo:

1. Minimnya Biaya Operasional

Dinas Lingkungan Hidup Kabupaten Tebo dalam rangka mengawasi dengan cara turun ke lapangan pasti menghadapi kendala-kendala. Pengawasan langsung yang dilakukan oleh Dinas Lingkungan Hidup belum optimal. Apa yang dijelaskan oleh pihak Dinas Lingkungan Hidup kenyataannya berbeda dengan pengawasan langsung yang terjadi di lapangan. Dinas Lingkungan Hidup menjelaskan bahwa pengawasan langsung dilakukan sekali enam bulan seperti yang telah diatur dalam SK Rencana Kerja Bidang Pengendalian Pencemaran dan Kerusakan Lingkungan Hidup, padahal nyatanya hanya dilakukan sekali setahun, dan jika ada laporan dari masyarakat baru dilakukan pengawasan hal ini dengan alasan keterbatasan dana atau biaya operasional.

Seharusnya Dinas Lingkungan Hidup melakukan pengawasan langsung sesuai dengan prosedur yang telah dibuat, yaitu sekali enam bulan, atau lebih baik sekali sebulan agar pengolahan limbah cair PT. Perkebunan Nusantara VI (Persero) maupun pabrik kelapa sawit lain dapat dibuang sesuai dengan baku mutu air limbah yang telah ditetapkan. Pengawasan ini dilakukan untuk mencegah adanya pencemaran pada badan air atau sungai didekat pabrik kelapa sawit yang dapat mengganggu aktivitas masyarakat setempat.

2. Faktor terbatasnya SDM (Sumber Daya Manusia)

Minimnya jumlah pengawas dan SDM handal pada Dinas Lingkungan Hidup dan Perhubungan Kabupaten Tebo telah menjadi hambatan dalam pengawasan terhadap pengelolaan limbah pada kawasan industri minyak kelapa sawit Kecamatan Rimbo Ilir Kabupaten Tebo. Adanya keterbatasan Dinas Lingkungan Hidup dan Perhubungan Kabupaten Tebo dalam melakukan pengawasan yakni minimnya SDM yang terdapat pada dinas tersebut, dengan minimnya rekrutmen PNS tentu tidak dapat menambah petugas pengawas, sedangkan jika menggunakan tenaga kontrak pastinya tidak memiliki kewenangan dalam melakukan pengawasan.

\section{Penutup}

Berdasarkan uraian dan analisis yang telah di kemukakan pada bab-bab terdahulu, dalam bab ini peneliti dapat mengemukakan beberapa hal sebagai kesimpulan atas pokok permasalahan dalam penelitian ini, Kesimpulan dari penelitian ini adalah 1) pengawasan yang dilakukan oleh Dinas Lingkungan Hidup dalam mengatasi pencemaran lingkungan pada kawasan industri minyak kelapa sawit Kecamatan Rimbo Ilir Kabupaten Tebo belum efektif. Hal ini dikarenakan PT. Perkebunan Nusantara VI (Persero) Rimbo Bujang masih membuang limbah cair melalui parit dan anak sungai yang bermuara ke Sungai Alay sehingga menyebabkan pencemaran. Meskipun Dinas Lingkungan Hidup telah melakukan pengawasan, antara lain: a. Pengawasan Langsung dan b. Pengawasan Tidak Langsung. 2) Beberapa hambatan pengawasan Dinas Lingkungan Hidup terhadap pengelolaan air limbah industri minyak kelapa sawit Kecamatan Rimbo Ilir Kabupaten Tebo, diantaranya adalah: a. Faktor cuaca dan b. Faktor terbatasnya SDM (Sumber Daya Manusia).

Saran dari penulis adalah diperlukan ketegasan Dinas Lingkungan Hidup dalam mengatasi pencemaran lingkungan pada kawasan industri minyak kelapa sawit Kecamatan Rimbo Ilir Kabupaten Tebo dengan memberikan sanksi jika perusahaan masih membuah limbah cair ke Sungai Alay.penelitian ini adalah 1) Strategi pemerintah desa dalam mengelola sawah TKD (Tanah Kas Desa) di Desa 


\section{Referensi}

Seling Kecamatan Tabir Kabupaten Merangin yaitu: a. Pernjanjian secara lisan; b. Melakukan optimalisasi pemasukan; c. Melakukan optimalisasi penggunaan lahan; d. Pengajuan Perbaikan Irigasi kepada Pemerintah Daerah. 2) Kendala yang dihadapi pemerintahan desa dalam mengelola sawah TKD (Tanah Kas Desa) di Desa Seling Kecamatan Tabir Kabupaten Merangin adalah a. Minimnya infrastrukur pertanian; b. Belum terbentuknya BUMDes. Saran dari penulis adalah 1) perlu dukungan dari Pemerintah Daerah khusunya Dinas Pertanian agar memberikan fasilitas pertanian bagi pemerintah desa agar desa dapat mandiri. 2) perlu binaan dari pemerintah daerah khususnya Dinas Pemberdayaan Masyarakat dan Pemerintah Desa Kabupaten Merangin agar dapat dibentuk BUMDes di Desa Seling guna meningkatkan pendapatan asli desa. Keberadaan BUMDes menjadi salah satu program untuk peningkatkan perekonomian masyarakat, agar dapat lebih memajukan kesejahteraan rakyat. Kalau saat ini mungkin belum ada efeknya keekonomi karena masih baru digerakan. Nanti kedepan kita harapkan ini jadi usaha untuk peningkatkan perekonomian.

Awang, Azam. (2020). Implementasi Pemberdayaan Pemerintah Desa. Pustaka Belajar, Ndraha, Talaziduhu. (1997). Metodologi Ilmu Pemerintahan. PT Rineka Cipta.

Peraturan Bupati Nomor 20 Tahun 2020 Tentang Jenis Usaha Dan/Atau Kegiatan Yang Wajib Menyusun Dokumen Upaya Pengelolaan Lingkungan Hidup Dan Upaya Pemantauan Lingkungan Hidup (UKL-UPL) Dan Surat Pernyataan Pengelolaan Lingkungan Hidup (SPPL).

Rosana, M. (2018). Kebijakan pembangunan berkelanjutan yang berwawasan lingkungan di Indonesia. Kelola: Jurnal Sosial Politik, 1(1), 148-163.

Setianingtias, R., Baiquni, M., \& Kurniawan, A. (2019). Pemodelan indikator tujuan pembangunan berkelanjutan di Indonesia. Jurnal Ekonomi Dan Pembangunan, 27(2), 6174.

Syafi'ie, Inu Kencana. (2003). Kepemimpinan Pemerintahan Indonesia. Refika Aditama.

Undang-Undang Nomor 32 Tahun 2009 Tentang Perlindungan dan Pengelolaan Lingkungan Hidup. 